IISSN: 2224-0616

Int. J. Agril. Res. Innov. \& Tech. 2 (1): 42-46, J une, 2012

Available online at http:/ / www.ijarit.webs.com

\title{
SUITABILITY OF DUCKWEED (Lemna minor) AS FEED FOR FISH IN POLYCULTURE SYSTEM
}

\author{
M.Z.H. Talukdar, M. Shahjahan* and M.S. Rahman \\ Received 21 February 2012, Revised 29 March 2012, Accepted 15 June 2012, Published online 30 June 2012
}

\begin{abstract}
In the present study, we conducted an experiment to evaluate the effects of duckweed (Lemna minor) as feed on fish production in polyculture. The experiment had 2 treatments where in treatment 1 (T1) ponds were supplied with duckweed as feed and in treatment 2 (T2) ponds were kept as control (without supply of duckweed). Average survival rates in T1 and T2 were 90 and 89\%, respectively. The specific growth rates (SGR) were higher in T1. Calculated net production in T1 was 6.25 tons ha.- $\mathrm{yr}^{-1}$ and in T2 was 2.84 tons ha.- ${ }^{-1} \mathrm{yr}^{-1}$. The ranges of physico-chemical parameters analyzed were within the productive limit and more or less similar in all the ponds under both treatments during the experimental period. There were 24 genera of phytoplankton under 5 major groups and 10 genera of zooplankton under 3 major groups found in the experimental ponds. The net production in T1 was significantly higher than that of T2 indicated the use of duckweed as feed for fishes is economically sustainable in polyculture.
\end{abstract}

Keywords: Duckweed, polyculture, fish, feed, production, pond, water quality

Department of Fisheries Management, Bangladesh Agricultural University, Mymensingh-2202, Bangladesh.

*Corresponding author's email: shahjahanm75@yahoo.co.uk (M. Shahjahan)

Reviewed by Dr. Binay Kumar Chakraborty, Matshya Bhabon, Romna, Dhaka, Bangladesh.

\section{Introduction}

Aquaculture in Bangladesh has rapidly progressed in recent years with a contribution of $44 \%$ to the annual fish production. Among different techniques of aquaculture, polyculture is one of the most important techniques. The basic principle of fish polyculture systems rests on the idea that when compatible species of different feeding habits are cultured together in the same pond, the maximum utilization of all natural food sources takes place without harmful effects. Polyculture or mixed culture of carps has been found as an economically viable and technically sustainable in perennial water bodies (Alikhuni, 1957; Chen, 1976). The selection of fish species is very important for polyculture systems. In the present study, tilapia (Oreochromi mossambicus), sharpunti (Barbades gonionotus), grass carp (Ctenopharyngodon idella), catla (Catla catla) and mrigal (Cirrhinus mrigala) were selected for polyculture. These species are suitable for low inputs culture system in small ponds and ditches for their quick growth and for maximum production within short period. Bangladesh has numerous seasonal water bodies in the form of shallow ponds, ditches, roadside canals, pits in rice fields, which retain water for 46 months. The natural environment of Bangladesh is also suitable for growing these fish species, which can be cultured in both shallow seasonal ponds and deeper perennial ponds.
Duckweed are small floating aquatic plants which are widely available in Bangladesh and consist of four genera viz., Lemna, Spirodela, Wolfia and Wolfiella among which about 40 species have been identified (Journey et al., 1991; Skillikorn et al., 1993). Duckweed can easily grow abundantly with minimum cost and can be made available as much cheaper feed than other alternative plant protein sources. Recently duckweed has been accepted as protein rich (40$45 \%$ of the dry weight) feed for fish (Landolt and Kandeler, 1987; Leng et al., 1995; Saha et al., 1999). According to Porath and Agami (1977), the weight of grass carp could be tripled (from 100 to $300 \mathrm{~g}$ ) within 50 days when feeding a mixture of Lemna gibba and Lemna minor. Duckweed protein has higher concentration of essential amino acids, lysine and methionine than most plant proteins and more closely resembles animal protein in that respect (Journey et al., 1991). In Bangladesh, many studies have been carried out on the use of duckweed as feed for fishes in monoculture (Kohinoor et al., 1993; Bornali, 2004; Haque, 2005; Uddin et al., 2007; Chowdhury et al., 2008), but so far, few works have been carried out in polyculture system. In the present study, we conducted an experiment to evaluate the effect of duckweed (Lemna minor) as feed on the fish production in polyculture system. 


\section{Materials and Methods \\ Duration of study}

The experiment was conducted for a period of 90 days in the earthen ponds each measuring 1 decimal $\left(40-\mathrm{m}^{2}\right)$ area at Bangladesh Agricultural University, Mymensingh, Bangladesh.

\section{Pond preparation}

Before fish stocking water of the experimental ponds were drained out to eradicate all the undesirable fishes, renovated and liming was done in all the ponds at the rate of $1 \mathrm{~kg} 40 \mathrm{~m}^{-2}$. Ponds were filled up with deep tube well water and fertilized with poultry dropping $10 \mathrm{~kg}$, urea

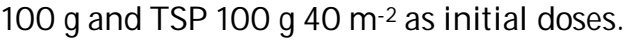

\section{Stocking of fish}

The experiment had two treatments each with three replications. In $\mathrm{T}_{1}$, ponds were supplied with duckweed as supplementary fish feed and in $\mathrm{T}_{2}$, ponds were kept as control (without supply of duckweed). Ponds were stocked at a stocking density of 151 fingerlings per decimal $\left(40-\mathrm{m}^{2}\right)$ at the ratio of tilapia: sharpunti: grass carp: catla: mrigal =45: 38: 15: 38: 15 .

\section{Fertilization and supply of duckweed}

The ponds were fertilized fortnightly with poultry dropping $10 \mathrm{~kg}$, urea $60 \mathrm{~g}$ and TSP $90 \mathrm{~g}$ per $40 \mathrm{~m}^{2}$ to grow natural food phytoplankton and zooplankton. Fresh duckweeds were supplied everyday to the ponds $\left(\mathrm{T}_{1}\right)$ at the rate of $50 \%$ of the total body weight (wet weight basis) of the fish.

\section{Physico-chemical parameters}

Various physical and chemical water quality parameters of the ponds such as water temperature $\left({ }^{\circ} \mathrm{C}\right)$, transparency $(\mathrm{cm})$, dissolved oxygen $\left(\mathrm{mg} \mathrm{L}^{-1}\right), \mathrm{pH}$, free $\mathrm{CO}_{2}\left(\mathrm{mg} \mathrm{L}^{-1}\right)$, total alkalinity $\left(\mathrm{mg} \mathrm{L}^{-1}\right), \mathrm{PO}_{4}-\mathrm{P}\left(\mathrm{mg} \mathrm{L}^{-1}\right)$ and $\mathrm{NO}_{3}-\mathrm{N}(\mathrm{mg}$ $\left.\mathrm{L}^{-1}\right)$ were estimated fortnightly. Water temperature was recorded with a Celsius thermometer and transparency was measured with a Secchi disc of $30 \mathrm{~cm}$ diameter. Dissolved oxygen was measured directly with a DO meter (Lutron, DO-5509) and a portable digital $\mathrm{pH}$ meter was used to measure $\mathrm{pH}$. Free $\mathrm{CO}_{2}$ and total alkalinity were determined by titrimetric method (APHA, 1992). $\mathrm{PO}_{4}-\mathrm{P}\left(\mathrm{mg} \mathrm{L}^{-1}\right)$ and $\mathrm{NO}_{3}-\mathrm{N}$ $\left(\mathrm{mgL}^{-1}\right)$ were determined by a Hach Kit (DR/2010, a direct reading Spectrophotometer).

\section{Biological parameters}

Biological parameters of ponds water such as phytoplankton density (cells $\mathrm{L}^{-1}$ ) and zooplankton density (cells L-1) were estimated fortnightly. The counting of plankton (both phytoplankton and zooplankton) was done with the help of SedgwickRafter Counting Cell (S-R cell) under a compound binocular microscope. The plankton population was determined by using the formula of Rahman (1992). Identification of plankton (phytoplankton and zooplankton) up to generic level were made according to Prescott (1964), Needham and Needham (1963) and Belcher and Swale (1978).

\section{Survival, growth and production of fish}

Fish samples were collected with a cast net monthly to estimate the growth in length $(\mathrm{cm})$ and in weight $(\mathrm{g})$ and to check up the health condition of fish. At the end of the experiment, all fish were harvested through repeated netting by seine net to calculate gross and net production of fish.

The survival rate was estimated by the following formula:

Survival rate (\%) $=\frac{\text { No. of harvested fishes }}{\text { Initial No. of fishes }} \times 100$

Specific growth rate (SGR, percent per day) was estimated by the following formula:

$$
\mathrm{SGR}(\% \text { per day })=\frac{\text { Loge } \mathrm{W}_{2}-\text { Loge } \mathrm{W}_{1}}{\mathrm{~T}_{2}-\mathrm{T}_{1}} \times 100
$$

Where, $\mathrm{W}_{1}=$ Initial live body weight ( $g$ ) at time $\mathrm{T}_{1}$ (day) $\mathrm{W}_{2}=$ Final live body weight $(\mathrm{g})$ at time $\mathrm{T}_{2}$ (day)

\section{Statistical analysis}

Values are expressed as means \pm standard deviation (SD). Data were analyzed by one-way analysis of variance (ANOVA) followed by Tukey's post hoc test to test for statistically significant differences between treatments. Statistical significance was set at $\mathrm{p}<0.05$. Statistical analyses were performed using SPSS Version 14.0 for Windows (SPSS Inc., Chicago, IL).

\section{Results and Discussion}

The present study was conducted to evaluate the suitability of duckweed as feed for fishes in polyculture of tilapia, sharpunti, grass carp, catla and mrigal. The supply of duckweed at the rate of $50 \%$ of body weight of fishes showed better production performance.

\section{Physico-chemical parameters}

The physico-chemical parameters such as water temperature $\left({ }^{\circ} \mathrm{C}\right)$, transparency $(\mathrm{cm})$, dissolved oxygen $\left(\mathrm{mg} \mathrm{L}^{-1}\right), \mathrm{pH}$, free $\mathrm{CO}_{2}\left(\mathrm{mg} \mathrm{L}^{-1}\right)$, total alkalinity $\left(\mathrm{mg} \mathrm{L}^{-1}\right), \mathrm{PO}_{4}-\mathrm{P}\left(\mathrm{mg} \mathrm{L}^{-1}\right)$ and $\mathrm{NO}_{3}-\mathrm{N}$ (mg L-1) of the ponds were found to be within the acceptable ranges for fish culture (Table 1). There was no abrupt change in any parameter of the pond water during the tenure of experiment. The results were more or less similar to the findings of Wahab et al., (1995), Kohinoor et al., (1998), Uddin et al., (2007) and Chowdhury et al., (2008). 
Table 1. Physico-chemical parameters (Means $\pm \mathrm{SD}$ ) of the experimental ponds during the experimental period

\begin{tabular}{lcccc}
\hline \multirow{2}{*}{ Parameters } & \multicolumn{4}{c}{ Treatments } \\
\cline { 2 - 5 } & \multicolumn{2}{c}{ Treatment 1 } & \multicolumn{2}{c}{ Treatment2 } \\
\cline { 2 - 5 } & Means & SD & Means & SD \\
\hline Water temperature $\left({ }^{\circ} \mathrm{C}\right)$ & 28.02 & 1.57 & 27.92 & 1.49 \\
Transparency $(\mathrm{cm})$ & 30.50 & 2.97 & 32.08 & 4.21 \\
Dissolved oxygen $\left(\mathrm{mgL}^{-1}\right)$ & 6.63 & 0.50 & 6.23 & 0.79 \\
$\mathrm{pH}$ & 7.45 & 0.21 & 7.43 & 0.19 \\
Free $\mathrm{CO}_{2}\left(\mathrm{mgL}^{-1}\right)$ & 2.85 & 0.30 & 2.90 & 0.28 \\
Alkalinity $\left(\mathrm{mgL}^{-1}\right)$ & 75.33 & 7.40 & 74.00 & 8.30 \\
Phosphate-phosphorous(mgL-1) & 0.59 & 0.11 & 0.64 & 0.07 \\
Nitrate-nitrogen(mgL-1) & 1.80 & 0.08 & 1.54 & 0.18 \\
\hline
\end{tabular}

\section{Biological parameters}

Fortnightly fluctuation of phytoplankton density (cells $\mathrm{L}^{-1}$ ) and zooplankton density (cells $\mathrm{L}^{-1}$ ) are shown in Table 2 . The average density of phytoplankton of the ponds under T1 was $53.98 \pm$ 4.74 (x103) cells $\mathrm{L}^{-1}$ and that of the ponds under T2 was $47.60 \pm 4.07\left(\mathrm{x}^{1} 0^{3}\right)$ cells $\mathrm{L}^{-1}$. The average density of zooplankton of the ponds under T1 was
$10.02 \pm 0.94\left(\mathrm{x} 10^{3}\right)$ cells $\mathrm{L}^{-1}$ and that of the ponds under T2 was $8.27 \pm 0.76\left(\mathrm{x}^{1} 0^{3}\right)$ cells $\mathrm{L}^{-1}$. The generic status of phytoplankton and zooplankton found during the tenure of experiment are shown in Table 3. Phytoplankton and zooplankton population in number and genera were more or less similar to the findings of Uddin et al., (2007) and Chowdhury et al., (2008).

Table 2. Fortnightly fluctuation of phytoplankton and zooplankton densities in the ponds during the experimental period.

\begin{tabular}{|c|c|c|c|c|c|c|c|c|}
\hline \multirow[b]{2}{*}{ Parameters } & \multirow[b]{2}{*}{ Treatments } & \multicolumn{6}{|c|}{ Sampling days } & \multirow[b]{2}{*}{ Means \pm SD } \\
\hline & & 1 & 2 & 3 & 4 & 5 & 6 & \\
\hline \multirow{2}{*}{$\begin{array}{l}\text { Phytoplankton } \\
\text { (x103 cells L-1) }\end{array}$} & T1 & 47.30 & 49.70 & 54.30 & 60.00 & 55.20 & 57.40 & $53.98 \pm 4.74$ \\
\hline & $\mathrm{T} 2$ & 47.60 & 51.70 & 40.90 & 45.10 & 51.10 & 49.20 & $47.60 \pm 4.07$ \\
\hline Zooplankton & T1 & 9.90 & 10.60 & 8.40 & 10.90 & 10.70 & 9.60 & $10.02 \pm 0.94$ \\
\hline$\left(\mathrm{x} 10^{3}\right.$ cells L L $\left.^{-1}\right)$ & T2 & 7.90 & 7.50 & 9.40 & 8.10 & 9.00 & 7.70 & $8.27 \pm 0.76$ \\
\hline
\end{tabular}

Table 3. Generic status of phytoplankton and zooplankton found in the experimental ponds

\begin{tabular}{lcl}
\hline & Phytoplankton & Zooplankton \\
\hline Bacillariophyceae & Cyanophyceae & Cladocera \\
Asterionella & Anabaena & Daphnia \\
Cyclotella & Aphanocapsa & Diaphanosoma \\
Diatoma & Chroococcus & \\
Fragilaria & Gomphospaeria & Copepoda \\
Navicula & Microcystis & Cyclops \\
Tabellaria & Oscillatoria & Diaptomus \\
& & Rotifera \\
Chlorophyceae & Dinophyceae & Asplanchna \\
Actinastrum & Ceratium & Brachionus \\
Chlorella & & Filinia \\
Closterium & Euglenophyceae & Keratella \\
Gloeocystis & Euglena & Polyarthra \\
Oocystis & Phacus & Trichocerca \\
Pediastrum & & \\
Scenedesmus & & \\
Ulothrix & & \\
Volvox & & \\
\hline
\end{tabular}

Survival, growth and production of fish

The survival rate of fishes in $\mathrm{T}_{1}$ and $\mathrm{T}_{2}$ were 90 and $89 \%$, respectively (Table 3 ). More or less similar survival rates were observed in polyculture system (Mostaque, 1995) and monoculture of Thai sharpunti (Kohinoor et al., 1993). The specific growth rate (SGR) of tilapia, sharpunti, grass carp, catla and mrigal were $0.99,1.03,1.51,-0.08$ and 2.00 in $\mathrm{T}_{1}$, and 0.65 , $0.83,0.58,-0.003$ and 1.86 in $\mathrm{T}_{2}$, respectively 
(Table 4). SGR values in $\mathrm{T}_{1}$ were higher than those in $\mathrm{T}_{2}$ except catla. Catla showed negative growth rate in both treatments, most probably it could not compete successfully with other fishes. SGR values obtained in the present study are similar to those obtained by Hossain et al., (1997). It can be said that the higher specific growth rate in $\mathrm{T}_{1}$ was due to use of duckweed as feed for fishes.

Table 4. Survival, growth rate of individual fish species during the experimental period

\begin{tabular}{llccccc}
\hline Treatments & $\begin{array}{l}\text { Species } \\
\text { stocked }\end{array}$ & $\begin{array}{c}\text { Stocking } \\
\text { density (No. } \\
\left.\text { per 40 } \mathrm{m}^{2}\right)\end{array}$ & $\begin{array}{c}\text { Survival } \\
\text { rate (\%) }\end{array}$ & $\begin{array}{c}\text { Average } \\
\text { initial weight } \\
(\mathrm{g})\end{array}$ & $\begin{array}{c}\text { Average } \\
\text { final weight } \\
(\mathrm{g})\end{array}$ & $\begin{array}{c}\text { Specific } \\
\text { growth rate }\end{array}$ \\
\hline \multirow{4}{*}{$\mathrm{T} 1$} & 45 & 82 & 32.67 & 68.92 & 0.99 \\
& Tilapia & 45 & 88 & 30.33 & 65.67 & 1.03 \\
& Sharputi & 38 & 96 & 74.33 & 231.03 & 1.51 \\
& Grass carp & 15 & 82 & 28.47 & 26.82 & -0.08 \\
& Catla & 38 & 10.83 & 18.83 & 84.69 & 2.00 \\
\hline \multirow{4}{*}{ T2 } & Mrigal & 15 & 100 & 32.67 & 53.11 & 0.65 \\
& Tilapia & 45 & 82 & 30.33 & 56.72 & 0.83 \\
& Sharputi & 38 & 88 & 74.33 & 115.38 & 0.58 \\
& Grass carp & 15 & 86 & 28.47 & 28.40 & -0.03 \\
& Catla & 38 & 90 & 18.83 & 74.00 & 1.86 \\
\hline
\end{tabular}

The calculated net production of fish of the ponds under $\mathrm{T}_{1}$ was $6.25 \pm 1.07$ tons ha. ${ }^{-1} \mathrm{yr}^{-1}$ and those of the ponds under $\mathrm{T}_{2}$ were $2.84 \pm 0.85$ tons ha. ${ }^{-1}$ yr. ${ }^{-1}$, respectively (Fig. 1). The net productions of fish were significantly higher in $\mathrm{T}_{1}$ might be due to supply of duckweed as feed. More or less similar productions were recorded in duck weed-based polyculture system (Mazumder et al., 1999; Kabir 2003). The effectiveness of duckweed as low cost supplementary feed was observed through 6 months production trial of Thai sharpunti

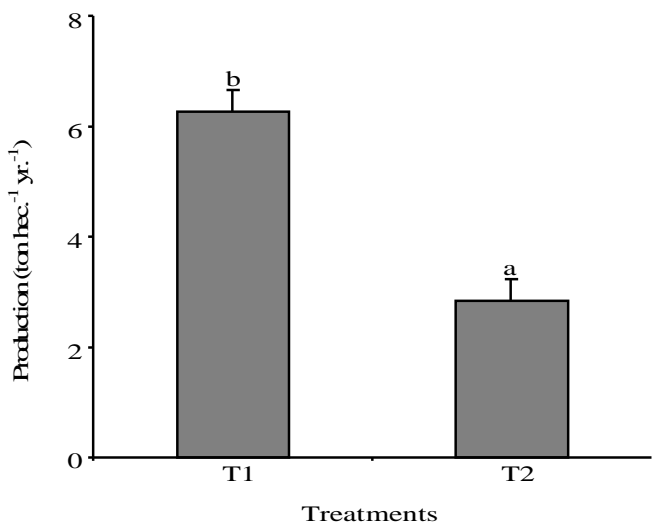

Fig. 1. Net production (means $\pm \mathrm{SD} ; \mathrm{n}=3$ ) of fish in two treatments. Values accompanied by different letters are statistically significantly different $(\mathrm{p}<0.05)$.

In conclusion, suitability of duckweed as feed for fishes was analyzed in polyculture system. Most of the water quality parameters of the ponds under $\mathrm{T}_{1}$ and $\mathrm{T}_{2}$ were more or less similar but the higher production of fish was recorded in $\mathrm{T}_{1}$. The reason behind the higher production in $\mathrm{T}_{1}$ was due to supply of duckweed as feed. Influence of duckweed on production of fish is positively significant indicated that duckweed might be used as preferable feed items for fishes in polyculture.
(Kohinoor et al., 1999). The production was significantly higher in ponds with supply of duckweed than that of the ponds without supply of duckweed in monoculture of tilapia (Bornali, 2004; Uddin et al., 2007; Chowdhury et al., 2008) and sharpunti (Haque, 2005). Considering the present and previous study, it is clear that duckweed is a suitable feed items for fishes in both monoculture and polyculture system.

\section{References}

Alikhuni, K.H. 1957. Fish culture in India. F.M. Bull. Indian Coun. Agric. Res., 20: 144.

APHA (American Public Health Association), 1992. Standard Methods for the Examination of Water and Wastewater. American Public Health Association, Washington DC. p. 874.

Belcher, H. and Swale E. 1978. A Beginner's Guide to Freshwater Algae. HMSO, London. p. 47. 
Bornali, K. 2004. Effect of duckweed (Lemna minor) as supplementary feed on monoculture of tilapia (Oreochromis niloticus). MS thesis. Mymensingh: Bangladesh Agricultural University. 104p.

Chen, T.P. 1976. Aquaculture practices in Taiwan. Fishing News (Books) Ltd., West Byfleet, Surrey, England. 124p.

Chowdhury, M.M.R., Shahjahan M., Rahman, M.S. and Sadiqul Islam M. 2008. Duckweed (Lemna minor) as supplementary feed in monoculture of nile tilapia, Oreochromis niloticus. J. Fisheries \& Aquatic Sci., 3: 5459.

Haque, M.S. 2005. Use of duckweed (Lemna minor) as supplementary feed in monoculture of sharpunti (Puntius gonionotus). MS thesis. Mymensingh: Bangladesh Agricultural University. 94 p.

Hossain, M.A., Ahmed, M. and Islam, M.N. 1997. Mixed culture of fishes in seasonal ponds through fertilization and feeding. Bangladesh J. Fisheries Res., 1: 9-18.

Journey, T., Skillicorn, P. and Spira, B. 1991. Duckweed aquaculture: A new aquatic farming system for developing countries. Emena Technical Department, World Bank.

Kabir, A.N.M.A. 2003. Use of duckweed (Lemna minor) as feed for fishes in polyculture. MS thesis. Mymensingh: Bangladesh Agricultural University. 97p.

Kohinoor, A.H.M., Akteruzzaman, M. and Shah, M.S. 1993. Red tilapia production potential under low input management in Bangladesh. 3rd Asian Fisheries Forum, Octobor 26-30, World Trade Center, Singapore.

Kohinoor, A.H.M., Islam, M.L., Wahab, M.A. and Thilsted, S.H. 1998. Effect of mola (Amblypharyngodon mola Ham.) on the growth and production of carps in polyculture. Bangldesh J. Fisheries Res., 2: 119-126.

Kohinoor, A.H.M., Islam, M.S., Begum, N. and Hussain, M.G. 1999. Production of thai sharpunti (Barbodes gonionotus Bleeker) in polyculture with carps using low-cost feed. Bangldesh J . Fisheries Res., 3: 157-164.

Landolt, E. and Kandeler, R. 1987. The family of Lemnaceae a monographic study. Veroffentlichungen Des Geobotanischen
Institute der Edg. Tech. Hochschule, Stiftung Ruebel, Zuerich. 638p.

Leng, R.A., Stambolie, J.H. and Bell, R. 1995. Duckweed: A potential high-protein feed resource for domestic animal and fish. AAAP Conf. Proc. Bali. 1: 103-114.

Mazumder, D., Kohinoor, A.H.M., Islam, T. and Tripathi, S.D. 1999. Low-cost, weed-based sustainable aquaculture system for seasonal water-logged rice-fields. Bangldesh J . Fisheries Res., 22: 79-83.

Mostaque, A. 1995. Studies on the mixed culture of fishes in seasonal ponds through fertilization and feeding. MS thesis. Mymensingh: Bangladesh Agricultural University. 107p.

Needham, J.G. and Needham, P.R. 1963. A Guide to Study of Freshwater Biology. 5th Edn., Holden-Day, Inc., San Francisco, 106 p.

Porath, D. and Agami, M. 1977. Enhancement of protein production in fish ponds with duckweed (Lemnaceae). Israel J. Bot., 26: 51-51.

Prescott, G.W. 1964. Algae of Western Great Lakes area. Wm. C. Brown Co. Dubuque, IOWA, 946 p.

Rahman, M.S. 1992. Water Quality Management: Aquaculture. BRAC Prokashana, Mohakhali, Dhaka, Bangladesh. $84 \mathrm{p}$.

Saha, J.K., Rahmatullah, S.M. and Mazid, M.A. 1999. Optimization of stocking density of duckweed, Wolffia arhiza (Linn.) and Lemna sp. Bangldesh J. Fisheries Res., 7: 161-168.

Skillikorn, P., Spira, W. and J ourney, T. 1993. Duckweed aquaculture. A New Aquatic Farming System for Developing Countries. The World Bank, Washington DC, 68 p.

Uddin, M.N., Rahman, M.S. and Shahjahan M. 2007. Effects of duckweed (Lemna minor) as supplementary feed on monoculture of GIFT strain of tilapia (Oreochromis niloticus). Progressive Agriculture, 18: 183-188.

Wahab, M.A., Ahmed, Z.F., Islam, M.A. and Rahmatullah, S.M. 1995. Effect of introduction of common carp, Cyprinus carpio (L.) on the pond ecology and growth of fish in polyculture. Aquaculture Research, 26: 619-628. 